\title{
Transnationalism, integration och etnisk organisering
}

\author{
En studie av svenska etniska organisationer i ljuset \\ av civilsambällets omvandling
}

\section{Transnationalism, integration and ethnic organizations. A study of Swedish ethnic organizations in light of the transnationalization of civil society.}

This article explores the activities of Swedish ethnic organizations. More specifically it explores how this organizational field has changed in light of more wide-ranging transformations of the Swedish civil society. The article is based on a study of the annual reports of ethnic organizations $(\mathrm{N}=52)$ that received a grant from the Swedish Agency for Youth and Civil Society (MUCF) in 2017, as well as 17 interviews with representatives of the said organizations. The study found indications of both path-dependent continuity and change. The ethnic organizations had maintained a longstanding focus on cultural activities of various kinds. Moreover, the influence of the study associations (studieförbund), and thus, the popular movement model (folkrörelsemodellen), was still substantial. In terms of change, in order to promote integration, some organizations appear to have taken on the role of service-producer, primarily to help members to navigate in relation to various Swedish public authorities. In addition, the study found that some ethnic organizations had become involved in new types of transnational governance networks with Swedish authorities, sending states, transnational migrant organizations and aid organizations. There are also indications of a "transnationalization" of opinion formation-activities in that some of them are aimed at a broader, international audience.

Keywords: integration, ethnicity, migration, civil society, popular movements

UNDER DE SENASTE decennierna har det svenska civilsamhället förändrats som en följd av såväl den tilltagande globaliseringen som inhemska förändringar. Den tidigare dominerande folkrörelsemodellen har över tid omvandlats och utmanats av nya organisatoriska praktiker och strömningar. Som Wijkström (2015) samt Reuter, Wijkström och Emami (2017) framhåller har de korporativistiska banden mellan myndigheter och folkrörelser försvagats, vilket medfört förändringar i roll- och arbetsfördelningen mellan myndigheter, civilsamhälle och näringsliv. Därtill finns en transnationell aspekt av civilsamhällets omvandling som består i att nya transnationella möjligheter uppstått, samtidigt som nationalstatliga institutioner inte längre har samma särställning som 
tidigare, vilket påverkat förutsättningarna för civilsamhällelig verksamhet och politik. Med transnationell aktivitet avses olika former av ekonomiska, sociala, kulturella och politiska relationer som överskrider internationella gränser (Collyer \& King 2015). Dessa förändringar har medfört att en rad nya sätt att bedriva civilsamhällelig verksamhet har utvecklats inom ramen för den redan existerande civilsamhälleliga organisationsfloran. Enligt Wijkström (2017) har organisatoriska praktiker med rötterna i folkrörelsemodellen i ökande utsträckning kombinerats med verksamheter som rör sig utanför folkrörelseorganisationernas institutionaliserade format och kanaler. Civilsamhällets mångfald har således ökat i takt med att nya organisatoriska hybridformer med både lokala och globala rötter har vuxit fram. Det innebär att civilsamhället som struktur inom vilken individer och grupper kan engagera sig och driva sina intressen har förändrats, vilket i sin tur kan få konsekvenser för hur samhällsstyrning och politik kommer till utryck i samhället som helhet, exempelvis genom att transnationella intressen kan få större genomslag i svensk politik och vice versa.

I ljuset av ovan beskrivna omvandlingar fokuserar föreliggande artikel på en avgränsad del av det svenska civilsamhället, nämligen svenska etniska organisationer. De etniska organisationerna är i regel invandrarorganisationer, men i Sverige görs ingen formell åtskillnad mellan invandrarorganisationer och etniska organisationer. Organisationer som bildats på etnisk grund och som ägnar sig åt "verksamheter som rör kultur, språk, identitet och delaktighet i samhället" kallas etniska organisationer av Myndigheten för ungdoms- och civilsamhällesfrågor (MUCF), som ansvarar för att dela ut statsbidrag till desamma (MUCF 2018:17).

För att kvalificera sig för bidrag avsedda för etniska organisationer krävs att minst 51 procent av medlemmarna har utländsk bakgrund. Därutöver förutsätts att organisationerna är ideella och att de har minst 1000 betalande medlemmar, vilka kan vara anslutna till lokalföreningar eller olika avdelningar. Vi har i denna studie begränsat oss till att studera de riksförbund för etniska organisationer i Sverige som mottagit stöd från MUCF. Dessa riksförbund är ideella organisationer med etniska organisationer som medlemmar. Tilläggas kan att merparten av dessa etniska organisationer är invandrarorganisationer i så måtto att de har kopplingar till andra geografiska områden än Sverige.

De ovan beskrivna tendenser som präglar hela det svenska civilsamhället går även att notera inom det etniska organisationsfältet. Fram till slutet av 1980-talet var de etniska organisationer som uppbar bidrag från staten tydligt kopplade till folkrörelsemodellen och det korporativistiska styrsystemet. Den korporativa regleringen av fältet har gradvis luckrats upp sedan 1980-talet (Borevi 2004; Scaramuzzino 2013). Samtidigt har förutsättningarna för transnationella aktiviteter och samarbeten mellan individer och organisationer i sändarländer - det vill säga länder från vilka migranter utvandrar - och mottagarländer - länder som tar emot migranter - underlättats då kostnaderna för internationell kommunikation och mobilitet har minskat kraftigt. Det internationella intresset för invandrarorganisationers transnationella relationer och aktiviteter har också vuxit på senare tid, eftersom forskning visat 
att dessa utgör viktiga kanaler för enskilda migranters transnationella engagemang (Portes \& Fernández-Kelly 2015; Snel, Hart \& van Bochove 2016). Det finns ingen övergripande forskning om hur det svenska etniska organisationsfältet som helhet har utvecklats och förändrats i ljuset av det svenska civilsamhällets omvandling och transnationaliseringen. Enligt den övergripande forskning som finns, baserad på svenska etniska riksförbunds verksamhetsberättelser för åren 2000-2001, ägnade sig de etniska organisationerna främst åt kulturbevarande och integrationsfrämjande verksamheter, medan "hemlandsrelaterade funktioner" endast utgjorde en liten del av de aktiviteter som redovisades av riksförbunden (Dahlstedt 2003:68). Som Reuter, Wijkström och Emami (2017) framhåller behövs jämförande studier av hur nationellt orienterade civilsamhälleliga organisationspraktiker med rötter i folkrörelsemodellen påverkas av nyare typer av transnationell civilsamhällelig organisering.

Mot bakgrund av denna kunskapslucka och ovan skisserade samhällsutveckling utforskar denna studie svenska etniska organisationers verksamheter. Artikeln syftar till att undersöka de organisationspraktiker som utmärker svenska etniska organisationer, för att därigenom kasta ett jämförande ljus över hur - och i vilken mån - etablerade och nationellt orienterade civilsamhälleliga organisationspraktiker uppblandas med nyare former av transnationell civilsamhällelig organisering. Genom en empirisk kartläggning av de redovisade aktiviteterna inom samtliga statsstödda etniska organisationer bidrar studien till att öka kunskapen om hur denna del av det svenska civilsamhället utvecklats under 2000-talet. Därmed kan studien ge en bild av hur civilsamhällets omvandlingar kommit till uttryck inom det etniska organisationsfältet. För att öka kunskaperna om olika migrantgruppers organisering undersöks vidare huruvida de aktiviteter som svenska etniska organisationer arrangerar skiljer sig åt, samt hur dessa på olika sätt relaterar till omvärlden och sändarländerna. På så sätt bidrar studien till att öka kunskapen om hur denna del av det svenska civilsamhället utvecklats mot bakgrund av tilltagande globalisering.

Artikeln är upplagd på följande sätt: den inleds med en redogörelse av centrala teoretiska och begreppsliga överväganden. Därefter tecknas en bakgrund till studien, innan vi går igenom dess metod. Sedan följer en översiktlig analys av resultaten från studiens kvantitativa del. Detta följs av en mer detaljerad analys av de aktivitetstyper vi urskilt i källmaterialet. Slutligen sammanfattar vi och analyserar studiens resultat.

\section{Teoretiska reflektioner}

En studie av det svenska etniska organisationsfältet förutsätter ett förtydligande av vad som avses med organisatoriskt fält. Ett organisatoriskt fält definieras på följande sätt av DiMaggio och Powell (1983:148): "By organizational field, we mean those organizations that, in the aggregate, constitute a recognized area of institutional life: key suppliers, resource and product consumers, regulatory agencies, and other organizations that produce similar services or products”. Enligt Emami (2017:108) kan man tala om ett övergripande svenskt folkrörelsefält som präglas av en gemensam jargong och gemensamma ideal rörande vissa organisatoriska kännetecken 
såsom "medlemskap, interndemokrati och ett allmänt rättvise- och solidaritetspatos, som anger önskvärda och lämpliga sätt för fältets organisationer”. De institutioner som reglerar organisatoriska fält kan vara både formella - till exempel kodifierade genom lagstiftning - och informella - exempelvis normer, praxis och hävdvunna överenskommelser. Liksom individer i sociala fält - i Bourdieus mening - präglas organisatoriska fält av relativt beständiga maktordningar där olika kapitalformer reglerar organisationers relativa inflytande (Koinova 2018). Både inom och mellan organisationer har individer och grupper olika maktresurser beroende på deras varierande tillgång till olika former av kapital såsom socialt, kulturellt, ekonomiskt kapital eller humankapital (Bloch \& Hirsch 2018). De beständiga ordningar, det vill säga de organisationskonstellationer, regleringar och institutioner som tillsammans konstituerar ett fält, präglar även nybildade organisationer som söker sig till fältet i fråga. Som Emami (2017) framhåller påverkas invandrares organisering av nationella institutioner, av offentliga och privata finansieringsformer med medföljande resursberoenden, av tillgängliga och förespråkade organisationsformer samt av grundläggande principer för civilsamhällets organisering som sätter tonen för verksamheternas organisations- och ledningsstruktur. I en svensk kontext har folkrörelseorganisationerna länge utgjort en inflytelserik maktsfär, såväl ekonomiskt som institutionellt. Folkrörelseorganisationerna har därför kunnat påverka och forma nya organisationer som tillkommit inom flera olika civilsamhälleliga fält, såsom kulturföreningar, friluftsföreningar, kvinnoorganisationer och inte minst invandrarorganisationer som ofta inledningsvis saknat ekonomiskt och socialt kapital såsom kopplingar till olika myndigheter (Emami 2017).

I regel har organisationer även mer eller mindre institutionaliserade kopplingar till andra organisationer och organisatoriska fält, vilka över tid ofta etableras som institutionaliserade styrningsnätverk. Som Wijkström (2015) påpekar har partier, religiösa samfund, fackförbund och andra civilsamhälleliga organisationer över tid kommit att bli naturliga och legitima aktörer i olika offentliga beslutsprocesser, så till den grad att de kan liknas vid avtalsparter i det moderna nationella samhällskontraktet. Därtill ingår ofta organisationer, i synnerhet invandrarorganisationer, i olika transnationella sociala fält. Dessa fält är inte begränsade till endast invandrarorganisationer utan påverkas även av andra aktörer och organisationer, inte minst mottagarstater och sändarstater. Enligt Collyer och King (2015) kan transnationella fält bäst förstås som resultatet av ett samspel mellan migranter och olika intressenters försök att styra och dra fördel av deras aktiviteter. Invandrarorganisationers sociala fält inbegriper inte bara migranter och migrantorganisationer utan även offentliga och civilsamhälleliga aktörer på olika nivåer och i olika länder samt internationella organisationer, vilka på olika sätt försöker skapa eller utnyttja möjligheter, eller hantera utmaningar som uppstår i samband med olika migrationsprocesser (Campbell \& Afework 2015; Délano Alonso \& Mylonas 2019). Det innebär att invandrarorganisationer har väldigt olika förutsättningar för samverkan i de olika transnationella fält som de är delaktiga i. I vissa fall kan sändarstater blockera eller aktivt förtrycka migranters transnationella aktiviteter; i andra fall kan sändarstater 
främja transnationella kopplingar (Huynh \& Yiu 2015; Chaudhary \& Moss 2019). I detta sammanhang använder vi oss av begreppet styrningsnätverk. Styrningsnätverk kan definieras som nätverk mellan ömsesidigt beroende aktörer vilka genom förhandling och samarbete bidrar till någon form av samhällsstyrning (Torfing 2012). Utfallet ifråga om samhällsstyrning är avhängigt de samverkande aktörernas intressen och förhandlingar. Ett styrningsnätverk kan överlappa, komplettera eller stå i konflikt med de principer som reglerar omgivande sociala fält. Med andra ord: när nationalstatliga institutioner och etablerade ordningar förlorar sin särställning i samband med att transnationella möjligheter öppnas upp och nya organisatoriska hybridformer växer fram, kan detta påverka omgivande nationella institutionella ordningar på olika sätt. Klijn och Skelcher (2007) gör en åtskillnad mellan nätverk som är inkompatibla respektive kompletterande i förhållande till de normer som kringgärdar myndighetsutövning i en representativ demokrati. Legitimitetsproblem kan exempelvis uppstå om organisationer genom styrningsnätverk kringgår formella regelverk och institutioner, står i strid med dem eller utför uppgifter som normalt utförs av myndigheterna själva. Som Emami (2017:122) påpekar tenderar civilsamhälleliga organisationer att ha vitala "juridiska, politiska, normativa kulturella och ekonomiska relationer och bindningar till olika delar av nationalstaten". Detta kan medföra en tröskel för transnationellt organisatoriskt engagemang, eftersom det krävs resurser för att organisatoriskt överskrida nationsgränser. Nedan beskrivs kort hur folkrörelsefältet kommit att bilda en formerande kontext för dagens etniska organisationer i Sverige.

\section{Folkrörelsefältet och de etniska organisationerna}

Civilsamhället, närmare bestämt folkrörelserna i Sverige (och övriga Norden), fick under 1900-talet en unik politisk ställning då de involverades i olika politiska beslutsprocesser, inte minst genom representation i olika statliga styrelser. Folkrörelsernas politiska deltagande kom att utvecklas till att bli en institutionaliserad del av den svenska demokratiska och korporativa traditionen. Denna tradition utmärktes av institutionaliserade maktutbytesprocesser genom förhandlingar och kompromisser mellan staten och olika intresseorganisationer, vilka ägde rum inom ramen för korporativa plattformar (exempelvis arbetsmarknadens partsgemensamma organ), genom remissväsendet eller genom organisationers representation i statliga styrelser (Lundberg 2015; Reuter 2017). Folkrörelserna kom även att utgöra en källa till folklig legitimitet för den förda politiken, men även för samhällsordningen i bredare bemärkelse då de var förknippade med brett förankrade sociala identiteter. Därmed bidrog folkrörelserna till att inkorporera individer i den etablerade samhällsordningen, inte bara som enskilda medborgare utan även som medlemmar i olika civilsamhälleliga organisationer som kunde utöva inflytande över offentliga beslut, vilket är något som Takle (2015) framhåller. Den gradvisa politiska inkorporeringen av folkrörelseorganisationer i styrningen av den offentliga sektorn och olika korporativa institutioner motsvarades av en byråkratisering av folkrörelseorganisationerna, eftersom de införlivade många organisatoriska aspekter från förvaltningen och det politiska systemet. 
Detta fick till följd att folkrörelsernas organisering i flera avseenden kom att avspegla den offentliga sektorns struktur, exempelvis den tredelade indelningen i nationell, regional och lokal nivå (Reuter 2017). Parallellt med att folkrörelseorganisationernas medlemsantal och politiska inflytande ökade under efterkrigstiden, genomgick de en professionalisering då oavlönade medlemmars arbetsinsatser övertogs av avlönad, professionell personal. Samtidigt säkerställdes organisationernas resursbaser genom offentligt stöd som var kopplat till medlemskaderns storlek (Wijkström 2015).

Enligt Wijkström (2015) blev folkrörelseorganisationerna betydelsefulla inom det svenska politiska systemet i flera avseenden. Folkrörelserna fungerade både som plattformar som möjliggjorde en uppåtgående social mobilitet för enskilda medlemmar, och som kanaler genom vilka framtida politiska ledare kunde utvecklas och rekryteras. Med andra ord hade folkrörelserna en karriärfunktion - såtillvida att de möjliggjorde klassresor för individer som annars saknade erforderligt socialt och ekonomiskt kapital - samtidigt som de breddade rekryteringsbasen för det politiska etablissemanget. Dessutom blev folkrörelseorganisationerna och deras studieförbund viktiga utbildningsinstitutioner ifråga om grundläggande praktiska och teoretiska färdigheter i politik och förvaltning; de utvecklades därmed till ett slags demokratiskolor (Takle 2015). Folkrörelseorganisationerna fick till uppgift att träna olika medborgargrupper - såsom ungdomar, arbetare, kvinnor och invandrare - i det aktiva och fullvärdiga medborgarskapets konst, så att de därigenom tillgodogjorde sig de värderingar och färdigheter som krävdes för att verka inom det politiska och administrativa systemet. En viktig del av medborgarskapet för centrala samhällsgrupper formades alltså inom folkrörelseorganisationerna, vilka genom sin gräsrotsförankring utgjorde en viktig mobiliseringskanal för folkligt deltagande i offentliga beslutsprocesser. Folkrörelseorganisationerna hade alltså både en röstfunktion - i meningen folklig förbindelse till det politiska systemet - och en karriärfunktion som tjänade både enskilda individer och det politiska systemet (Wijkström 2015).

Schierup (1991b) och Dahlstedt, Ålund och Ålund (2010) har framhållit att folkrörelsemodellens fostrande och karaktärsdanande aspekter även inbegripit styrande och disciplinerande tendenser som riktats mot mindre etablerade grupper: först arbetarklassen och senare mot invandrare. När invandrare i Sverige började organisera sig under efterkrigstiden knöts de ofta till fält som dominerades av folkrörelserna. Inom dessa fält kunde de erbjudas långsiktigt stöd och samarbeten med studieförbund som Arbetarnas Bildningsförbund (ABF) och andra aktörer inom arbetarrörelsen (Odmalm 2004:107). Sedan 1960-talet har de etniska organisationerna utvecklat nära relationer till studieförbunden, särskilt i fråga om samarbeten kring olika utbildningsprogram och språkundervisning (Dahlstedt, Ålund \& Ålund 2010). ABF har exempelvis haft stor betydelse för många svenska invandrarorganisationer, inte minst under deras uppstartsfaser då $\mathrm{ABF}$ gett råd om hur man söker föreningsstöd samt hur man löser interna organisationskonflikter och dylikt. Flera invandrargrupper valde att organisera sig genom att bilda organisationer baserade på etnisk grund samt skapa nationella förbund av folkrörelsesnitt. Detta var lockande eftersom de ofta saknade resurser i form av socialt och ekonomiskt kapital eller tidigare erfa- 
renheter av föreningsliv. Genom att bilda riksförbund stärktes organisationernas legitimitet och de kunde lättare få tillgång till offentligt stöd samt samarbeten med myndigheter och andra riksförbund (Emami 2017).

Frågan om huruvida invandrare genom stöd ska uppmuntras att bevara sina särdrag och organisera sig enligt etniska principer eller inte har emellertid varit omdebatterad sedan 1960-talet. Enligt Dahlström (2004) har den svenska politiska diskussionen kring regleringen av etniska organisationer kontinuerligt pendlat mellan två motsatta ståndpunkter: å ena sidan ett mångkulturellt perspektiv som bejakar invandrares bevarande av sin kulturella särart genom olika former av statligt stöd, å andra sidan en mer integrationsfrämjande uppfattning.

I praktiken har handlingsutrymmet för de etniska organisationerna varierat över tid. Schierup (1991a) har framhållit det tidigare dominerande korporativa systemets begränsande och disciplinerande aspekter. Vid 1980-talets början hade de etniska organisationerna inlemmats i en korporativistisk ordning som var nära knuten till arbetarrörelsen, fackföreningarna och det socialdemokratiska partiet. Inom ramen för detta system var Statens invandrarverk (SIV) ålagt att granska de statsstödda etniska organisationernas aktiviteter. De etniska organisationerna var skyldiga att underordna sig ett riksförbund för att kunna få ekonomiskt stöd samt för att underlätta samarbetet och koordineringen med SIV, som i sin tur agerade som ett slags mellanhand i relation till andra myndigheter och civilsamhälleliga organisationer. Schierup (1991b) menar att detta system kom att fungera som en sorts tvångströja för de etniska organisationerna, vilka hade svårt att agera utanför systemets ramar. Samtidigt har Emami (2004) påpekat att statens inflytande över föreningslivet via organisationsstöd i praktiken har varit begränsat, eftersom de bidragsgivande myndigheterna inte haft insyn i vad som sker inom föreningarna, utöver verksamhetsplaner och ekonomisk redovisning.

Sedan 1980-talet har det korporativistiska systemet, liksom de administrativa strukturer som kringgärdat stödet till etniska organisationer, förändrats i grunden. Som inledningsvis nämndes är den svenska modellen och dess civilsamhälleliga förgreningar under omvandling. De täta banden mellan staten och olika intresseorganisationer som kännetecknade det korporativistiska systemet började lösas upp under 1990-talet när statliga myndigheter och styrelser inte längre efterfrågade representanter för folkrörelseorganisationer och intressegrupper (Reuter 2017). Samtidigt tillsatte den borgerliga regeringen 1991-1994 en beredning i syfte att underlätta för ideella organisationer att erbjuda tjänster som kompletterade de offentliga välfärdsorganisationerna. Den riktning som inleddes under det borgerliga regeringsinnehavet på 1990-talet följdes upp av den borgerliga alliansregeringen 2006-2014. Detta bidrog till en större öppenhet från statens sida gentemot nya typer av organisationer inom civilsamhället (utöver de etablerade folkrörelseorganisationerna), samtidigt som staten intog en mer exkluderande hållning gentemot exempelvis fackföreningarna. Därtill verkade alliansregeringen för att ge ett ökat utrymme för civilsamhälleliga organisationer som var serviceproducenter eller välfärdsleverantörer, en tendens som Wijkström (2015) beskrivit som ett skifte från röst 
till service. Det betyder dock inte att organisationer med rötter i folkrörelsemodellen har försvunnit, utan snarare att mångfalden av organisationstyper i den svenska civilsamhälleliga organisationsfloran har ökat (Wijkström 2015).

Även det etniska organisationsfältet har påverkats av dessa omvandlingar. Till att börja med har de administrativa förutsättningarna för de etniska organisationerna förändrats i grunden sedan korporativismens glansdagar. I slutet av 1990-talet överfördes ansvaret för förvaltningen av anslagen till de etniska organisationerna från SIV till en nybildad myndighet, Integrationsverket. Parallellt med att den korporativa regleringen minskade infördes en ny typ av styrning som uppmuntrade integrationsfrämjande verksamheter, vilket ledde till minskade bidrag åt organisationer som huvudsakligen ägnade sig åt kulturbevarande aktiviteter. Båda målsättningarna kvarstod emellertid (Borevi 2004). Enligt Dahlstedt, Ålund och Ålund (2010) infördes dessutom förändringar i bidragsystemet i syfte att främja institutionell samverkan och integrationsfrämjande samarbeten mellan statliga och kommunala myndigheter samt civilsamhälleliga och privata organisationer. Som en följd av detta har fler etniska organisationer inriktat sig på integrationsarbete med fokus på utbildning, demokrati, antidiskriminering och lönearbete. Denna verksamhet har kompletterat offentliga integrations- och utbildningssatsningar, samtidigt som mångfalden av verksamhetsformer inom området har ökat (Dahlstedt, Ålund \& Ålund 2010). Även Scaramuzzino (2013) pekar på att de etniska organisationerna kommit att ingå i fler horisontella samarbeten med myndigheter och andra delar av civilsamhället under 2000-talet.

Integrationsverket lades ned 2007 och ansvaret för anslagen till de etniska organisationerna överfördes till Ungdomsstyrelsen, som 2014 bytte namn till Myndigheten för ungdoms- och civilsamhällesfrågor (MUCF). I den ännu gällande förordningen "om statsbidrag till organisationer bildade på etnisk grund" (SFS 2008:63) - som antogs efter att Ungdomsstyrelsen tagit över ansvaret för dessa anslag - betonas att statsbidrag till organisationer bildade på etnisk grund syftar till att stärka verksamheter som rör kultur, språk och identitet såväl som delaktighet i samhället. De etniska organisationerna har emellertid ett ganska stort handlingsutrymme i formell mening. MUCF (2018:17) framhåller att statsbidragen till organisationer bildade på etnisk grund skiljer sig från andra organisationsbidrag såtillvida att de inte explicit "anger någon förväntad effekt på samhälls- eller individnivå för målgruppens ställning", samtidigt som myndigheten betonar att begreppet delaktighet "antyder att insatserna bör leda till ökad delaktighet i samhället för målgrupper och medlemmar". Det finns alltså inga snävare villkor kopplade till de statsbidrag som riktas till etniska organisationer. Det är mot denna bakgrund som föreliggande studie undersöker de aktiviteter som redovisats av de etniska organisationernas riksförbund. 


\section{Metod}

Studien bygger på en totalundersökning av de 52 riksförbund som fick bidrag från MUCF för år 2017 och har inlämnat en verksamhetsberättelse för detta år. Totalt ingick 58 organisationer i den undersökta stödkategorin, men av dessa var fem centralorganisationer för andra riksförbund, nämligen Immigranternas centralförbund, Immigranternas riksförbund, Internationella kvinnoförbundet, Riksförbundet Internationella Föreningar för Invandrarkvinnor (RIFI) och Samarbetsorgan för etniska organisationer i Sverige (SIOS). Dessa samarbetsorgan för riksförbunden inkluderades inte i studien eftersom de saknar lokala medlemsorganisationer. Därutöver föll det Irakiska Riksförbundet i Sverige bort då det inte hade inkommit med en verksamhetsberättelse för 2017.

Det huvudsakliga empiriska underlaget består av de 52 riksförbundens verksamhetsberättelser, vilka analyserades i både kvantitativt och kvalitativt hänseende. Inledningsvis kategoriserade vi aktiviteterna i verksamhetsberättelserna och inordnade dem i tolv aktivitetsklasser, vilka vi redogör för nedan. Därefter kartlade vi förekomsten av varje aktivitetstyp inom varje organisation.

Med utgångspunkt i Ragin (1987) skapade vi en databas genom att koda respektive aktivitetsklass med en etta om den förekom i en organisations årsrapport, och en nolla om den inte förekom. Vi kategoriserade därefter organisationerna på olika sätt. Till att börja med delade vi in organisationerna i fyra kategorier utifrån antalet medlemmar. Intervallen för dessa kategorier är 244-1 500 medlemmar (mycket liten organisation), 1 501-2 500 medlemmar (liten organisation), 2 501-5000 medlemmar (stor organisation) och 5 001-8 662 medlemmar (mycket stor organisation). Organisationerna kategoriserades därefter utifrån den tidsperiod de etablerades. Den första tidsperioden för etablerande (typ 1) vi urskilde sträcker sig från 1945 till 1969, då arbetskraftsinvandringen i princip upphörde. För åren därefter periodiserade vi decennievis fram till år 2000. Den femte perioden omfattar tiden 2000-2013, då den sista organisationen som inkluderades i studien grundades (se typindelning i Tabell 1). Vi delade även in organisationerna i fyra kategorier på grundval av medlemmarnas ursprungsregion: Europa, Mellanöstern och Nordafrika (MÖNA), Asien och Afrika söder om Sahara (se typindelning i Tabell 2). 
Tabell 1. Typindelning efter riksförbundens etableringsår.

\begin{tabular}{|c|c|c|c|c|}
\hline $\begin{array}{l}\text { Typ } 1 \\
(1945-1969)\end{array}$ & $\begin{array}{l}\text { Typ } 2 \\
(1970-1980)\end{array}$ & $\begin{array}{l}\text { Typ } 3 \\
(1981-1990)\end{array}$ & $\begin{array}{l}\text { Typ } 4 \\
(1991-2000)\end{array}$ & $\begin{array}{l}\text { Typ } 5 \\
(2001-2013)\end{array}$ \\
\hline \multirow{30}{*}{$\begin{array}{l}\text { Letternas } \\
\text { Riksförbund i } \\
\text { Sverige (1945) } \\
\text { Litauiska Fören- } \\
\text { ingen i Sverige } \\
\text { (1946) } \\
\text { Sverigeesternas } \\
\text { Förbund (1956) } \\
\text { Finlands- } \\
\text { svenskarnas } \\
\text { Riksförbund i } \\
\text { Sverige (1969). }\end{array}$} & \multirow{30}{*}{$\begin{array}{l}\text { Italienska FAIS-IR } \\
\text { (1970) } \\
\text { Jugoslaviska } \\
\text { Riksförbundet } \\
\text { (Serbernas Riksför- } \\
\text { bund i Sverige efter } \\
\text { 1992) (1970), } \\
\text { Grekiska Riks- } \\
\text { förbundet (1972) } \\
\text { Ungerska Riks- } \\
\text { förbundet (1974) } \\
\text { Assyriska Riks- } \\
\text { förbundet i Sverige } \\
\text { och Polska Riks- } \\
\text { förbundet (1977) } \\
\text { Kroatiska Riks- } \\
\text { förbundet (1978) } \\
\text { Portugisiska Riks- } \\
\text { förbundet F.A.P.S. } \\
\text { (1980). }\end{array}$} & \multirow{3}{*}{$\begin{array}{l}\text { Eritreanska } \\
\text { Riksförbundet i } \\
\text { Sverige } \\
\text { Kurdiska Riksför- } \\
\text { bundet (1981) }\end{array}$} & $\begin{array}{l}\text { Slovenska Riks- } \\
\text { förbundet (1991) }\end{array}$ & $\begin{array}{l}\text { Ryska Riksförbundet i } \\
\text { Sverige (2003) }\end{array}$ \\
\hline & & & \multirow{3}{*}{$\begin{array}{l}\text { Bosnisk- } \\
\text { Hercegovinska } \\
\text { Riksförbundet i } \\
\text { Sverige (1991) }\end{array}$} & \multirow{2}{*}{$\begin{array}{l}\text { Somaliska Institutet för } \\
\text { Demokratiska Alterna- } \\
\text { tiv }(2003)\end{array}$} \\
\hline & & & & \\
\hline & & \multirow{2}{*}{$\begin{array}{l}\text { Polska Kongressen } \\
\text { i Sverige (1982) }\end{array}$} & & \multirow{2}{*}{$\begin{array}{l}\text { Albanska Föreningars } \\
\text { Union i Sverige }\end{array}$} \\
\hline & & & \multirow{2}{*}{$\begin{array}{l}\text { Makedoniska Riks- } \\
\text { förbundet (1992) }\end{array}$} & \\
\hline & & Eritreanska & & Iransk och Kurdisk \\
\hline & & Riksförbundet i & \multirow{2}{*}{$\begin{array}{l}\text { Serbiska Riksför- } \\
\text { bundet (1992) }\end{array}$} & \multirow{3}{*}{$\begin{array}{l}\text { Integrations Riksför- } \\
\text { bund i Sverige (I.K.I.R) } \\
(2004)\end{array}$} \\
\hline & & Sverige & & \\
\hline & & \multirow{2}{*}{$\begin{array}{l}\text { Syriska Riksför- } \\
\text { bundet (1987) }\end{array}$} & \multirow{4}{*}{$\begin{array}{l}\text { Armeniska Riks- } \\
\text { förbundet i Sverige } \\
\text { och Kurdiska Rådet } \\
\text { (1993) }\end{array}$} & \\
\hline & & & & \multirow{2}{*}{$\begin{array}{l}\text { Kaldeiska Riksförbund i } \\
\text { Sverige (2004) }\end{array}$} \\
\hline & & Afrosvenskarnas & & \\
\hline & & Riksförbund & & \multirow{3}{*}{$\begin{array}{l}\text { Albanska Riskförbundet } \\
\text { Iliria (2007) } \\
\text { Syensk-Kurdiska }\end{array}$} \\
\hline & & \multirow{18}{*}{$\begin{array}{l}\text { Iranska Flykting- } \\
\text { ars Riksförbund } \\
\text { (IFRS) (1990). }\end{array}$} & \multirow{2}{*}{$\begin{array}{l}\text { Iranska Riksförbun- } \\
\text { det i Sverige (1994) }\end{array}$} & \\
\hline & & & & \\
\hline & & & \multirow{2}{*}{$\begin{array}{l}\text { Bangladesh Riks- } \\
\text { förening i Sverige } \\
(1995)\end{array}$} & Riksförbundet (2007) \\
\hline & & & & $\begin{array}{l}\text { Kinesiska Riksförbun- } \\
\text { det i Sverige (2008) }\end{array}$ \\
\hline & & & \multirow{2}{*}{$\begin{array}{l}\text { Somaliska Riks- } \\
\text { förbundet i Sverige } \\
(1995)\end{array}$} & $\begin{array}{l}\text { Yarsan Riksförbund } \\
(2008)\end{array}$ \\
\hline & & & & Sveriges Kinesiska \\
\hline & & & \multirow{4}{*}{$\begin{array}{l}\text { Kurdiska Unionens } \\
\text { Riksförbund i } \\
\text { Sverige (1997) } \\
\text { Riksförbundet } \\
\text { Banjaluka i Sverige } \\
\text { (1997) }\end{array}$} & Riksförbund (2009) \\
\hline & & & & Ukrainska Alliansen i \\
\hline & & & & $\begin{array}{l}\text { Azarbajdzjaniers Kon- } \\
\text { gress i Sverige (2010) }\end{array}$ \\
\hline & & & & Mongoliska Riksfören- \\
\hline & & & \multirow{2}{*}{$\begin{array}{l}\text { Bosnien och } \\
\text { Hercegovinas } \\
\text { Kvinnoförbund i } \\
\text { Sverige (1998) }\end{array}$} & ing i Sverige (2011) \\
\hline & & & & $\begin{array}{l}\text { Sunbul Riksförbundet } \\
\text { (företräder somaliska } \\
\text { lokalföreningar) (2011) }\end{array}$ \\
\hline & & & \multirow{3}{*}{$\begin{array}{l}\text { Bosniskherce- } \\
\text { govinsk-Svenska } \\
\text { Kvinnoförbundet i } \\
\text { Sverige (1999) }\end{array}$} & Riksföreningen för \\
\hline & & & & Khaatumo State of \\
\hline & & & & Somalia (2012) \\
\hline & & & \multirow{2}{*}{$\begin{array}{l}\text { Somaliland Riks- } \\
\text { förbund i Sverige } \\
(1999)\end{array}$} & $\begin{array}{l}\text { Tanzaniska Riksförbun- } \\
\text { det i Sverige (2012) }\end{array}$ \\
\hline & & & & \multirow{2}{*}{$\begin{array}{l}\text { Riksförbundet Bi- } \\
\text { jeljina-Janja (2013). }\end{array}$} \\
\hline & & & $\begin{array}{l}\text { Sudanesiska Riks- } \\
\text { förbundet (1999). }\end{array}$ & \\
\hline
\end{tabular}


Tabell 2. Typindelning av riksförbunden efter ursprungsregion

\begin{tabular}{|c|c|c|c|}
\hline Europa & $\begin{array}{l}\text { Mellanöstern och } \\
\text { Nordafrika }\end{array}$ & Asien & Afrika \\
\hline $\begin{array}{l}\text { Letternas Riksförbund i } \\
\text { Sverige }\end{array}$ & $\begin{array}{l}\text { Assyriska Riksförbundet } \\
\text { i Sverige }\end{array}$ & $\begin{array}{l}\text { Armeniska Riksförbun- } \\
\text { det i Sverige }\end{array}$ & $\begin{array}{l}\text { ERIS (Eritreanska } \\
\text { Riksförbundet i Sverige) }\end{array}$ \\
\hline $\begin{array}{l}\text { Litauiska Föreningen i } \\
\text { Sverige }\end{array}$ & $\begin{array}{l}\text { Kurdiska Riksförbundet } \\
\text { Syriska Riksförbundet }\end{array}$ & $\begin{array}{l}\text { Bangladesh Riksfören- } \\
\text { ing i Sverige }\end{array}$ & $\begin{array}{l}\text { Afrosvenskarnas } \\
\text { Riksförbund }\end{array}$ \\
\hline $\begin{array}{l}\text { Sverigeesternas Förbund } \\
\text { Finlandssvenskarnas }\end{array}$ & $\begin{array}{l}\text { Iranska Flyktingars } \\
\text { Riksförbund (IFRS) }\end{array}$ & $\begin{array}{l}\text { Kinesiska Riksförbundet } \\
\text { i Sverige }\end{array}$ & $\begin{array}{l}\text { Somaliska Riksförbun- } \\
\text { det i Sverige }\end{array}$ \\
\hline Riksförbund i Sverige & Kurdiska Rådet & Sveriges Kinesiska & Djibouti Kvinnor \\
\hline $\begin{array}{l}\text { FAIS-IR (Italienska } \\
\text { riksförbundet) }\end{array}$ & $\begin{array}{l}\text { Iranska Riksförbundet i } \\
\text { Sverige }\end{array}$ & $\begin{array}{l}\text { Riksförbund } \\
\text { Azerbajdzjaniers }\end{array}$ & $\begin{array}{l}\text { Riksförbund } \\
\text { Somaliska Riksförbun- }\end{array}$ \\
\hline Serbernas Riksförbund i & Kurdiska Unionens & Kongress i Sverige & det i Sverige \\
\hline Sverige & Riksförbund i Sverige & Mongoliska Riksfören- & Sudanesiska Riksför- \\
\hline Grekiska Riksförbundet & Iransk och Kurdisk In- & & bundet \\
\hline $\begin{array}{l}\text { Ungerska Riksförbundet } \\
\text { Polska Riksförbundet }\end{array}$ & $\begin{array}{l}\text { tegrations Riksförbund i } \\
\text { Sverige (I.K.I.R) }\end{array}$ & & $\begin{array}{l}\text { Somaliska Institutet för } \\
\text { Demokratiska Alternativ }\end{array}$ \\
\hline $\begin{array}{l}\text { Kroatiska Riksförbundet } \\
\text { F.A.P.S. Portugisiska } \\
\text { Riksförbundet }\end{array}$ & $\begin{array}{l}\text { Kaldeiska Riksförbund } \\
\text { i Sverige } \\
\text { Svensk-Kurdiska }\end{array}$ & & $\begin{array}{l}\text { Riksföreningen for } \\
\text { Khaatumo State of } \\
\text { Somalia }\end{array}$ \\
\hline Polska Kongressen i Sverige & Riksförbundet & & Tanzaniska Riksförbun- \\
\hline Slovenska Riksförbundet & Yarsan Riksförbund & & \\
\hline $\begin{array}{l}\text { Bosnisk-Hercegovinska } \\
\text { Riksförbundet i Sverige }\end{array}$ & Sunbul Riksförbundet & & \\
\hline $\begin{array}{l}\text { Makedoniska Riks- } \\
\text { förbundet }\end{array}$ & & & \\
\hline Serbiska Riksförbundet & & & \\
\hline $\begin{array}{l}\text { Banjaluka National As- } \\
\text { sociations }\end{array}$ & & & \\
\hline $\begin{array}{l}\text { Bosnien och Hercegovinas } \\
\text { Kvinnoförbund i Sverige }\end{array}$ & & & \\
\hline $\begin{array}{l}\text { Bosniskhercegovinsk- } \\
\text { Svenska Kvinnoförbundet } \\
\text { i Sverige }\end{array}$ & & & \\
\hline $\begin{array}{l}\text { Ryska Riksförbundet i } \\
\text { Sverige }\end{array}$ & & & \\
\hline $\begin{array}{l}\text { Albanska Föreningars } \\
\text { Union i Sverige }\end{array}$ & & & \\
\hline $\begin{array}{l}\text { Albanska Riskförbundet } \\
\text { Iliria }\end{array}$ & & & \\
\hline $\begin{array}{l}\text { Ukrainska Alliansen i } \\
\text { Sverige }\end{array}$ & & & \\
\hline $\begin{array}{l}\text { Riksförbundet Bijeljina - } \\
\text { Janja }\end{array}$ & & & \\
\hline
\end{tabular}


Utifrån databasen kunde vi testa samband mellan oberoende variabler som organisationernas medlemsantal, medlemmarnas angivna ursprungsland eller region, organisationens ålder och storlek samt antalet aktivitetstyper. Eftersom organisationspopulationen $(\mathrm{N}=52)$ är begränsad har vi huvudsakligen använt de kvantitativa resultaten i deskriptiv och explorativ mening.

Utöver konstruktionen av en databas genomförde vi 17 semistrukturerade djupintervjuer med företrädare för några av riksförbunden. Vid analysen av intervjumaterialet identifierades olika teman som belyser olika aspekter av studiens frågeställningar. Urvalet av respondenter var stratifierat såtillvida att det syftade till att sprida respondenterna jämnt över kategorierna utifrån riksförbundens storlek, ålder och ursprungsregion. Av de intervjuade förbundsföreträdarna var tretton män och fyra kvinnor. Urvalet av respondenter syftade främst till att spegla olika typer av etniska organisationer. Vid urvalet tog vi hänsyn till de organisationer som respondenterna företrädde, snarare än respondenternas individuella bakgrundsvariabler såsom ålder och kön. Urvalet var även baserat på tillgänglighet då några av de tillfrågade förbundsrepresentanterna avböjde att medverka i studien, varför det inte kan sägas vara helt stratifierat. Detta kan innebära att vissa organisationskategorier inte fått samma utrymme i intervjustudien. I den del av studien som avhandlar relationen till ursprungslandet har vi valt att anonymisera några av organisationerna eftersom de uppgifter som står i fokus kan vara politiskt känsliga, exempelvis då en organisation enligt egen uppgift bevakades av ursprungslandets ambassad och underrättelsetjänst. Projektet har inte genomgått etikprövning då det redogör för data som bygger på offentliga handlingar och på intervjuer med riksförbundsföreträdare som gett sitt samtycke till att delta i studien.

\section{Resultat och analys}

\section{En översikt av organisationspopulationen}

De 52 riksförbund som ingår i studien har ett totalt medlemsantal om 127935 individer fördelade över 1046 lokala föreningar (se Tabell 3). Varje riksförbund hade i snitt nära 18 medlemsföreningar. Spridningen är stor då det minsta förbundet endast hade fyra medlemsföreningar, medan det största hade 58. De flesta organisationerna i studien (73 procent) har vi klassificerat som mycket små ( 42 procent) eller små (31 procent) medan 11,5 procent är stora och drygt 15 procent är mycket stora. 
Tabell 3. Översikt över riksförbunden

Medel Median Minimum Maximum

Total (per riksförbund)

\begin{tabular}{|c|c|c|c|c|c|}
\hline & & & & & \\
\hline Antal riksförbund & 52 & & & & \\
\hline $\begin{array}{l}\text { MUCF:s stöd } 2017 \\
\text { (SEK) }\end{array}$ & 18505000 & 319925 & 296825 & 80000 & 633073 \\
\hline $\begin{array}{l}\text { MUCF-stödets andel } \\
\text { av riksförbundets totala } \\
\text { inkomster }\end{array}$ & - & $55,6 \%$ & $65,5 \%$ & 0 & $99 \%$ \\
\hline Etableringsår & - & & 1994 & 1945 & 2013 \\
\hline Verksamhetsår & - & 23,3 & 20,5 & 2 & 70 \\
\hline Antal medlemmar & 127935 & 2460 & 1671 & 244 & 8662 \\
\hline Antal lokala föreningar & 1046 & 17,8 & 15,5 & 4 & 58 \\
\hline $\begin{array}{l}\text { Antal län med } \\
\text { verksamhet i }\end{array}$ & - & 6,9 & 7 & 2 & 15 \\
\hline
\end{tabular}

Könsfördelningen är ganska jämn, även om det redovisade antalet kvinnor är något högre (drygt 51 procent). Ifråga om ursprungsregion företrädde drygt 46 procent av organisationerna medlemmar med ursprung i Europa, drygt 23 procent medlemmar med ursprung i Mellanöstern och Nordafrika, drygt 19 procent Afrika söder om Sahara och 11,5 procent Asien. Samtliga sex asiatiska organisationer är små och mer än två tredjedelar (71 procent) av de totalt 24 europeiska riksförbunden är små eller väldigt små. Bland de tolv riksförbund som representerar medlemmar med ursprung i Mellanöstern och Nordafrika var fördelningen något jämnare då fem var stora, och sju små. Bland de tio afrikanska organisationerna var åtta små och två stora. Bidraget från MUCF utgjorde i snitt drygt hälften (56 procent) av organisationernas samlade intäkter, som i övrigt bestod av medlemsavgifter och andra intäkter.

Sett ur ett riksperspektiv utgjorde de etniska organisationerna i studien mindre än en halv procent av det totala antalet civilsamhälleliga organisationer i Sverige, som 2017 uppgick till 258000 inklusive fackföreningar och företagsorganisationer (SCB 2017). Mot denna bakgrund framstår de etniska organisationernas andel av den totala svenska civilsamhälleliga organisationspopulationen som mycket liten. Det fanns fler etniska organisationer i Sverige än de som ingår i studien men det svårt att uppskatta deras totala antal då de inte samlas under någon entydig verksamhetsindelningskategori i den offentliga statistiken. Det kan vidare vara mer rättvisande att göra kontextualiserade jämförelser, exempelvis genom att beakta specifika typer av civilsamhälleliga organisationer. Om man ställer antalet etniska lokalföreningar i de riksförbund som har 
studerats (det vill säga 1046 lokala föreningar) i relation till antalet idrottsföreningar inom Riksidrottsförbundets största medlemsförbund 2018 (3 251 fotbollsföreningar och 1288 gymnastikföreningar), framstår de etniska organisationerna som en ganska betydande organisationstyp inom det svenska föreningslivet. I jämförelse med kulturföreningar och humanitära hjälpföreningar utan etnisk inriktning utmärkte sig de etniska organisationerna med en högre anslutningsgrad. Enligt de nationella SOM-undersökningarna 1996-2013 var endast 0,1-0,18 procent medlemmar i lokala samhällsföreningar, pensionärsföreningar, kulturföreningar och humanitära hjälpföreningar (Boije \& Ottervik 2014). Då det totala antalet utrikes födda 2017 uppgick till 1 877050 personer är det möjligt att de etniska organisationernas anslutningsgrad bland 16-85-åringar inom denna grupp uppgår till någon eller några procent. Dessutom är det totala antalet medlemmar i etniska organisationer i Sverige sannolikt betydligt större om man även inkluderar etniska organisationer som inte fått stöd från MUCF. Bland utrikes födda kan alltså anslutningsgraden vara relativt hög i jämförelse med liknande organisationer inom befolkningen som helhet. Det är dock svårt att beräkna den exakta anslutningsgraden då medlemmarna i de etniska organisationerna i varierande grad inkluderar inrikes födda, exempelvis personer med utrikes födda föräldrar. Därtill råder stor osäkerhet ifråga om den befintliga statistikens tillförlitlighet.

\section{De etniska organisationernas framväxt över tid}

Samtliga etniska organisationer som ingår i studien etablerades under efterkrigstiden och framåt. Organisationernas tillkomsthistorier återspeglar sannolikt åtminstone delvis efterkrigstidens migrationsvågor. Letternas Riksförbund i Sverige grundades 1945 och är därmed den äldsta organisationen i studien. Störst antal etniska organisationer etablerades under 1990-talet (se Figur 1). I genomsnitt har de studerade etniska organisationerna varit verksamma i drygt 23 år.

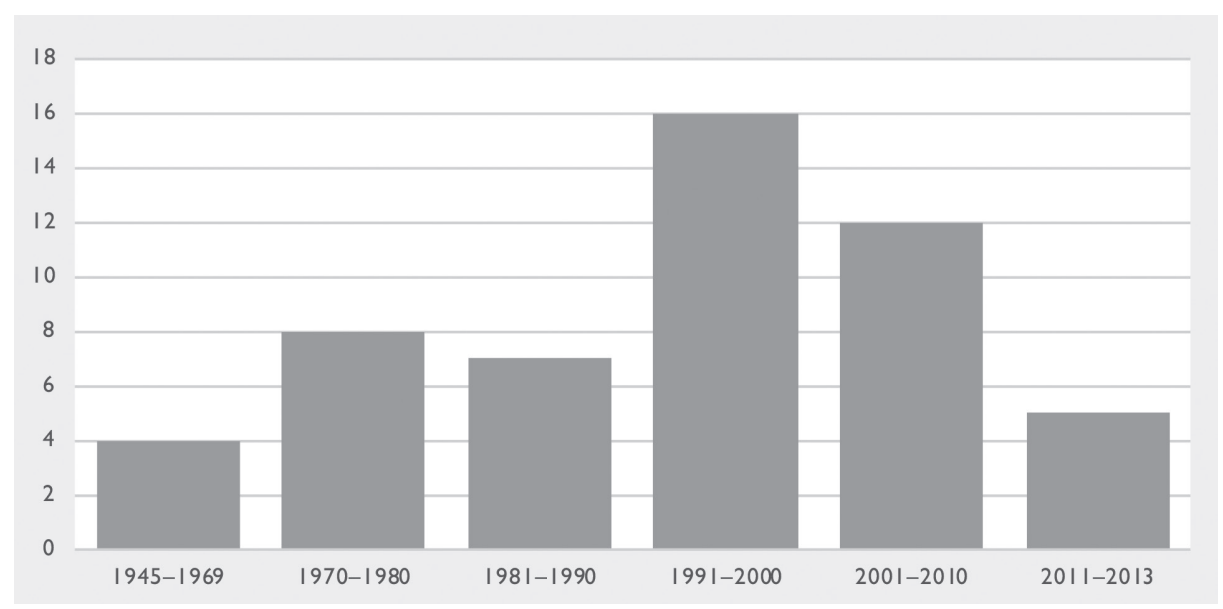

Figur 1. Antalet etablerade etniska organisationer över tid 
Under den första tidsperioden 1945-1969 etablerades de fyra första organisationerna av grupper som invandrat från närliggande länder kring Östersjön. Mellan 1970 och 1980 grundades åtta riksförbund, främst med ursprung i Syd- och Östeuropa. Under perioden 1981-1990 bildades sju etniska organisationer med en mer geografiskt varierad sammansättning. Under studiens fjärde period 1991-2000 tillkom 16 etniska organisationer. En delförklaring till att ungefär dubbelt så många organisationer uppstod under denna period jämfört med tidigare perioder är att den sammanföll med Jugoslaviens sammanbrott, vilket ledde till en uppsplittring av det Jugoslaviska riksförbundet. Vidare är det ökande antalet etniska organisationer sannolikt en avspegling av en fortsatt flyktinginvandring under 1980- och 1990-talen. Arton etniska organisationer med varierande ursprung grundades under studiens femte och sista period 2001-2013. Det relativt höga antalet nytillkomna organisationer under tjugohundratalet tycks delvis spegla en ökad förekomst av konkurrerande riksförbund inom vissa grupper, exempelvis kineser, somalier och bosnier, det vill säga nationaliteter som åtminstone i formell mening redan företräddes av en existerande organisation.

Det går inte att utifrån föreliggande studie dra några definitiva slutsatser om vad som kan tänkas ligga bakom det ökande antalet organisationer som representerar samma etniska grupp eller nationalitet. Förekomsten av flera olika etniska organisationer som representerar människor med samma ursprung kan spegla en tilltagande konkurrens om resurser eller inflytande mellan individer och grupper. I några fall bottnade uppbrotten i slitningar mellan manliga och kvinnliga medlemmar vilket ledde till att de senare brutit sig ur och formerat egna riksförbund. Det finns som nämnts två riksförbund som representerar kvinnor med ursprung i Bosnien: Bosnien och Hercegovinas Kvinnoförbund i Sverige och Bosniskhercegovinsk-Svenska Kvinnoförbundet i Sverige. Ytterligare kvinnoförbund med rötter i etniska riksförbund - såsom Kurdistans Kvinnoförbund i Sverige, Kinesiska riksförbundet i Sverige Kvinnokommitté och Sverigefinskt Kvinnoforum - har etablerats med hjälp av statsbidrag från Jämställdhetsmyndigheten avsedda för kvinnors organisering. Det statliga stödet till fälten i fråga har alltså i någon mån möjliggjort viss fragmentering, i vissa fall efter inomorganisatoriska slitningar. Därtill har antalet utrikes födda växt över tid, vilket kan ha bidragit till ökad heterogenitet i termer av politiska och organisatoriska intressen inom olika invandrargrupper. En annan möjlig bakgrundsförklaring är att villkoren för statsbidragen kan ha varit striktare under den tidsperiod då de handlades av SIV, samt att kraven på att varje etnisk grupp och nationalitet ska underordna sig ett riksförbund har lättats. En sådan omreglering kan ha möjliggjort en ökad förekomst av konkurrerande riksförbund bland grupper där medlemsföreningarna har haft olika intressen, identiteter eller politiska profiler. En slutsats är dock att mångfalden av organisationer inom det etniska organisationsfältet har ökat sedan 1990-talet. 


\section{Aktivitetsbredd och variation}

Som nämnts urskilde vi tolv olika aktivitetstyper och undersökte deras förekomst i årsrapporterna från de 52 riksförbund som ingår i studien. En generell översikt ger vid handen att det rådde ganska stor variation i fråga om bredden av aktivitetstyper som förbundens föreningar arrangerade. Den ena extremen utgjordes av två organisationer som redovisade tio olika typer av aktiviteter, den andra extremen utgjordes av två som endast redovisade en aktivitetstyp. Ett tiotal organisationer redovisade sex aktivitetstyper, vilket även var det vanligast förekommande antalet.

Om man beaktar organisationernas ålder uppvisade förbund som etablerades mellan 1981-1990 (typ 3) störst bredd i fråga om antal aktivitetstyper (se typindelning i Tabell 1). De äldsta (typ 1) och yngsta (typ 5) uppvisade minst aktivitetsbredd (4,5 respektive 4,8 i snitt), medan de förbund som grundades mellan 1970 och 2000 hade ett bredare aktivitetsutbud, närmare bestämt sex aktivitetstyper. Dessa skillnader förklaras delvis av att en större andel av de äldsta och yngsta organisationerna är mycket små. Det finns ett samband mellan det totala antalet aktiviteter och organisationernas storlek, vilket förklarar ungefär 15,5 procent av variansen avseende totala aktiviteter (eta ${ }^{2}=0,155$ ). Inom typ 1 var tre av fyra organisationer mycket små och en var liten. Inom typ 5 var mer än två tredjedelar (12 av 17 eller 70,5 procent) av organisationerna mycket små, nära en fjärdedel (23,5 procent) var små medan endast en var mycket stor. Ytterligare en förklaring till den lägre aktivitetsbredden bland yngre organisationer kan vara att det helt enkelt kan ta ganska lång tid att etablera en fungerande organisation, vilket Emami (2017) framhåller. Den låga aktivitetsbredden inom de äldsta organisationerna kan möjligen förklaras av att de representerar grupper som befunnit sig i landet länge och att de därför inte erbjuder integrationsfrämjande verksamheter, som vi ska se nedan. Det är även tänkbart att de inte attraherar yngre generationer med svagare band till ursprungslandet, varför aktivitetsbredden främst är inriktad på långtidsmedlemmar.

Organisationer som representerar medlemmar från Mellanöstern och Nordafrika (MÖNA-regionen) hade ett bredare genomsnittligt aktivitetsutbud om cirka sju aktivitetstyper jämfört med övriga organisationer som i snitt redovisade fyra till fem aktiviteter. Sambandet mellan ursprungsregion och det totala antalet aktivitetstyper förklarar ungefär 21 procent av variansen $\left(\mathrm{eta}^{2}=0,206\right)$ i den senare variabeln. En möjlig bakomliggande förklaring till denna skillnad i aktivitetsbredd är att organisationerna gör olika prioriteringar med utgångspunkt i skilda medlemsbehov. Ytterligare en bidragande förklaring kan vara att de större MÖNA-förbunden företräder stora migrantgrupper med medlemmar i olika åldrar och som levt i Sverige under olika lång tid, vilket skulle kunna leda till en mer varierande efterfrågan på olika aktivitetstyper. Som framgår nedan i den kombinerade redovisningen av det kvantitativa och kvalitativa datamaterialet har några av MÖNA-organisationerna bland annat riktat sig mot relativt nyanlända medlemmar, vilket kan ha resulterat i en bredare uppsättning aktivitetstyper. Om man beaktar de aktiviteter som vi klassificerat som arbetsmarknadsstödjande tycks det som om främst MÖNA-organisationerna aktivt arbetade för att främja integration och deltagande i det svenska samhället. Cirka två tredjedelar av MÖNA-organisationerna redovisade någon form av arbetsmarknadsorienterad aktivi- 
tet i syfte att hjälpa medlemmar att etablera sig på arbetsmarknaden, jämfört med en dryg femtedel av de europeiska förbunden. Detta antyder att de etniska organisationernas aktiviteter delvis verkar spegla respektive grupps ställning på arbetsmarknaden. Etniska organisationer där en högre andel i gruppen har en något svagare ställning på arbetsmarknaden tycks anpassa sina aktiviteter för att främja medlemmarnas integration. Att afrikanska och asiatiska förbund har en lägre andel dylika aktiviteter kan förklaras av att högre andel av dem är mycket små eller små, som vi sett ovan.

En övergripande tolkning av de ovan beskrivna skillnaderna i aktivitetsbredd är att de civilsamhälleliga omvandlingarna har haft olika effekt på olika delar av den studerade organisationspopulationen. I den mån det finns en trend i riktning mot ökad civilsamhällelig serviceproduktion tycks den främst ha berört organisationer som representerar grupper med en svagare ställning på arbetsmarknaden. De senare redovisar fler aktiviteter som syftar till att stödja och komplettera olika integrationsfrämjande myndighetsinsatser. Denna tendens framgår tydligare vid en närmare genomgång av de olika aktivitetstyperna.

\section{De etniska organisationernas aktivitetstyper}

\section{Kulturaktiviteter, högtidsfirande samt barn-, ungdoms- och idrottsaktiviteter}

Som nämnts ovan har nästan nio av tio riksförbund (46 av 52 eller 88,5 procent) det gemensamt att de ägnar sig åt olika former av kulturella aktiviteter, vilket antyder en slagsida mot språk-, identitets- och kulturbevarande aktiviteter (se Figur 2).

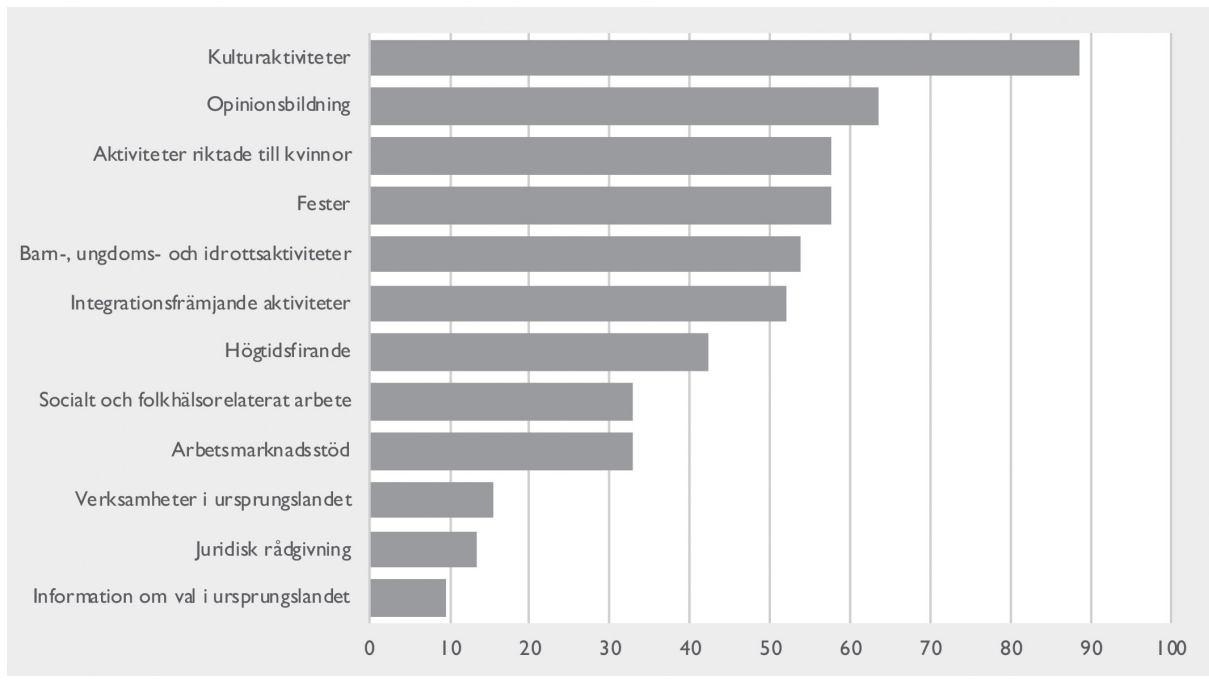

Figur 2. Förekomsten av olika aktivitetstyper i riksförbundens medlemsorganisationer (procent). 
Det gick inte att urskilja några väsentliga skillnader mellan de olika organisationerna på grundval av exempelvis ursprungsregion eller organisationernas ålder. Den kvalitativa genomgången gav dock en ganska varierad och komplex bild av de kulturella aktiviteterna. Som väntat förekom kulturella aktiviteter som just har ett kulturbevarande syfte, exempelvis kurser med syfte att tradera kunskaper om hemlandets litteratur, kultur och musiktraditioner, seminarier om ursprungslandets historia samt tillställningar med författare, musiker och poeter med anknytning till ursprungslandet, ofta i samarbete med studieförbund som ABF. 30 av 52 förbund (nära 58 procent) redovisade fester såsom fastlagsfirande (Ryska riksförbundet) eller firande av traditionella årshögtider (Kurdiska riksförbundet). 22 av de 52 förbunden (42,5 procent) redovisade även arrangemang kopplade till olika minneshögtider. Vissa av dessa aktiviteter hade ett uttalat identitets- eller kulturbevarande syfte. Exempelvis förekom minneshögtider kopplade till kollektiva trauman såsom folkmord (Armeniska riksförbundet), minneshögtider kopplade till andra världskrigets slut (Ryska riksförbundet) och nationaldagsfirande (Somaliska riksförbundet).

Dessa resultat kan tolkas som att det fanns en viss slagsida mot aktiviteter som syftar till att upprätthålla kulturell kontinuitet och därmed till ett bevarande av en viss form av etnisk identifikation förknippad med ursprungslandet. Aktiviteternas innehåll varierade emellertid. I vissa fall syftade de till att hjälpa medlemmarna att tolka och hantera olika integrationsproblem. Inom föreningar tillhörande det Assyriska riksförbundet gestaltade exempelvis en teatergrupp olika utmaningar förknippade med de slitningar som kan uppstå inom nyligen invandrade familjer i samband med att de etablerar sig i Sverige. Andra kulturella aktiviteter syftade till att förmedla en positiv bild av ursprungslandets kultur, exempelvis genom kulturfestivaler och dylikt. De kulturella aktiviteterna tycks alltså ha fungerat på olika sätt för olika grupper och individer, i kulturbevarande, gestaltande, sociala och performativa avseenden.

Detsamma kan sägas om barn-, ungdoms- och idrottsaktiviteter, vilka redovisades av drygt hälften (28 stycken eller nära 54 procent) av förbunden (se Figur 2). Det förekom inga nämnvärda skillnader mellan de olika organisationstyperna, utöver att endast två av åtta afrikanska organisationer redovisade denna aktivitetstyp, vilket kan sammanfalla med att dessa i regel var små förbund. Vissa av barn- och ungdomsaktiviteterna hade en uttalad språk-, identitets- och kulturbevarande orientering, men även här förkom variation. Upprätthållandet av ursprungslandets språk, kulturella identiteter och band till ursprungslandet var ett centralt mål för flera av barn- och ungdomsaktiviteterna. Detta gällde i synnerhet etniska organisationer som representerar grupper som befunnit sig i Sverige under längre tid, där yngre generationer riskerar att förlora kontakten med föräldragenerationens kultur. De intervjuade företrädarna för azerbajdzjanska, slovenska och serbiska riksförbunden betonade exempelvis vikten av att de barn som växer upp i Sverige ska lära sig ursprungslandets språk. Andra barn- och ungdomsaktiviteter var orienterade mot integration i Sverige. Det somaliska riksförbundets medlemsorganisationer erbjöd exempelvis stödundervisning åt barn och ungdomar, körkortslektioner samt verksamheter för att motverka extremism och underlätta arbetsmarknadsintegration. 
Sammantaget indikerar dessa resultat att aktivitetsområden kopplade till kultur-, barn-, ungdoms- och idrottsaktiviteter inom det etniska organisationsfältet primärt kännetecknades av kontinuitet snarare än förändring. I Dahlstedts (2003:64) studie dominerade de kulturella aktiviteterna samt idrotts-, barn- och ungdomsaktiviteter. Resultaten i den här studien talar för att det förblivit så över tid, även om dessa aktiviteter kan ha blivit något vanligare över tid. Dessutom förekom ofta samarbeten med studieförbund som ABF, vilket antyder att folkrörelsemodellen fortfarande var närvarande och utövade inflytande över fältet.

\section{Socialt och folkhälsoorienterat arbete, integrationsfrämjande aktiviteter samt kvin- noaktiviteter}

För socialt och folkhälsoorienterat arbete, integrationsfrämjande verksamheter samt kvinnoaktiviteter framträder skillnader mellan olika typer av riksförbund. Integrationsfrämjande aktiviteter - såsom hjälp vid myndighetskontakter, stöd till nyanlända och arbetsmarknadsorienterade verksamheter - redovisades av drygt hälften av riksförbuden (27 av 25) (se Figur 2). Dessa verksamheter inkluderar hjälp vid myndighetskontakter, stöd till nyanlända, arbetsmarknadsorienterade verksamheter samt aktiviteter som syftar till att hantera frågor som rör integration, kultur och religion.

Integrationsfrämjande verksamheter av detta slag var vanligare inom utomeuropeiska etniska organisationer. 9 av 24 (37,5 procent) organisationer med medlemmar från europeiska länder, jämfört med 8 av 12 (ca 67 procent) MÖNA-organisationer, 4 av 6 (ca 67 procent) asiatiska organisationer och 6 av 10 afrikanska organisationer redovisade integrationsfrämjande verksamheter. En förklaring till dessa skillnader tycks vara att etniska organisationer som representerar grupper från betydande flyktingländer prioriterar integrationsaktiviteter, sannolikt för att det även efterfrågas av medlemmarna. Genom intervjuerna framgick exempelvis att de kurdiska och syriska organisationerna påverkades kraftigt av flyktingvågen 2015. Efter flyktingtillströmningen arrangerade medlemsföreningar inom det syriska riksförbundet regelbundet mottagningar för att bistå nyanlända vid myndighetskontakter med skolor, hälsovården och kommunernas bostadsförmedlingar. Det finns även exempel på mer långsiktigt orienterat integrationsarbete. Medlemsorganisationer inom exempelvis de somaliska och sudanesiska riksförbunden anordnade regelbundet samhällsinformationsseminarier och föreläsningar med företrädare för svenska myndigheter, i samarbete med studieförbund som ABF och Studiefrämjandet.

Dessa resultat antyder att flera etniska organisationer iklätt sig rollen av förmedlare och informatörer, framför allt hjälp till medlemmar att hitta rätt bland olika myndigheter och välfärdsproducenter. I detta avseende går det att urskilja en tydlig tendens då inslag av service- och tjänsteproduktion framstår som ganska vanligt förekommande inom delar av det etniska organisationsfältet. Några av de etniska organisationerna tycks alltså ha utvecklats till att bli ett slags tjänsteproducenter, främst genom att komplettera myndigheter och välfärdsproducenter med fokus på att hjälpa medlemmar att navigera inom myndighetsfloran. Det är oklart vad detta beror på då MUCF inte kräver specifika resultat av de etniska organisationerna. En tänkbar förklaring är att 
det delvis avspeglar en spontan civilsamhällelig mobilisering som svar på omedelbara hjälpbehov, exempelvis bland nyanlända flyktingar. Det är därtill möjligt att vissa etniska organisationer uppvaktas mer än andra av studieförbund och myndigheter som erbjuder olika samarbeten som inbegriper integrationsfrämjande insatser. En tolkning är således att skiftet i riktning mot service eller tjänsteproduktion delvis är ett resultat av att myndigheter lagt mer fokus på integrationsfrämjande samarbeten med etniska organisationer i syfte att komplettera offentliga integrations- och utbildningssatsningar, vilket exempelvis Dahlstedt, Ålund och Ålund (2010) betonat.

Liknande tendenser finns inom arbetsmarknadsorienterade verksamheter, exempelvis kurser i hur man skriver cv eller hur man förbereder sig inför jobbintervjuer. Dessa aktiviteter är förstås också integrationsfrämjande men vi har ändå valt att redovisa dem separat för att ge en något tydligare bild av vilken typ av integrationsverksamhet som avses. Skillnaderna mellan de olika organisationerna var påtagliga även i detta avseende. Drygt två tredjedelar (8 av 12) av MÖNA-organisationerna redovisade arbetsmarknadsorienterade verksamheter, jämfört med cirka en tredjedel (3 av 10) av de afrikanska organisationerna, en dryg femtedel (5 av 24) av de europeiska och endast en av sex asiatiska organisationer. Sannolikt kan dessa resultat delvis förklaras av att organisationerna svarade mot skilda medlemsbehov. Representanterna för de armeniska, ryska, och serbiska riksförbunden framhöll att deras medlemsföreningar inte ägnade sig åt integrations- eller arbetsmarknadsorienterade aktiviteter eftersom medlemmarna i regel var välintegrerade på arbetsmarknaden och i samhället i stort. Detta talar för att de etniska organisationerna inriktade sig mot olika former av integration, i den mån ett behov av detta hade identifierats. De etniska organisationerna tycks alltså vid behov drivas till att försöka motverka segregation snarare än att huvudsakligen ägna sig åt språk- och kulturbevarande aktiviteter. Det är möjligt att myndigheter och studieförbund har bidragit till att identifiera olika integrationsbehov samt att myndigheters samarbetserbjudanden och studieförbundens kursutbud också kan ha påverkat verksamheternas inriktning.

30 av de 52 organisationerna (eller nära 58 procent) redovisade även aktiviteter och verksamheter särskilt riktade till kvinnor (se Figur 2). Kvinnokommittén inom ett av MÖNA-riksförbunden arbetade exempelvis för att främja kvinnors rättigheter och integration på flera olika sätt, bland annat genom att förbereda kvinnor som varit hemmafruar i ursprungslandet inför de krav på deltagande i arbetsmarknaden som ställs i Sverige. Medlemsföreningar inom de ryska och iranska riksförbunden erbjöd bland annat juridisk rådgivning riktad mot kvinnor i behov av stöd och råd i familjerättsliga frågor, exempelvis vid skilsmässor. Det fanns också projekt som syftade till att minska våld mot kvinnor. I den tidigare jämförbara forskning som finns, det vill säga Dahlstedts (2003) studie, redovisas inte kvinnoverksamheter som en separat kategori i den kvantitativa översikten. Projekt och kurser med fokus på kvinnor omnämns, men omfattningen framgår inte. Föreliggande studie antyder att denna verksamhetsform har fått större utrymme över tid.

Det förekom skillnader mellan de etniska organisationerna avseende kvinnoverksamheter. 5 av 6 asiatiska organisationer (ca 83 procent) redovisade verksamheter 
riktade till kvinnor jämfört med 8 av 12 (ca 67 procent) av MÖNA-organisationerna, 13 av 24 (ca 54 procent) av de europeiska och 4 av 10 afrikanska organisationer. Vidare var verksamheter riktade till kvinnor vanligast inom de yngre förbunden och minst vanligt förekommande inom de äldre förbunden. Inom de yngsta (typ 5) redovisade 12 av 17 organisationer, det vill säga drygt två tredjedelar, verksamheter riktade mot kvinnor. Inom typ 3 och 4 var alltså andelen något lägre, cirka 60 procent, och bland de äldsta organisationerna (typ 1 och 2 ) betydligt lägre (1 av 4 respektive 3 av 8).

Vi kan inte fastställa vad dessa skillnader kan bero på. Sannolikt är det delvis en generationsfråga då jämställdhetsfrågor kan ha fått ett större genomslag inom yngre etniska organisationer. Det kan finnas en tröghet och en spårbundenhet i de äldre organisationerna som medför att de håller sig till de aktiviteter som etablerades i ett tidigare skede av sin historia. Det är vidare möjligt att en högre andel kvinnliga medlemmar inom de asiatiska och MÖNA-organisationerna har identifierat etniska organisationer som en viktig plattform för att driva frågor som de prioriterar. Att framhålla aktiviteter riktade till kvinnor i årsrapporterna kan också vara ett sätt att öka ett riksförbunds legitimitet i förhållande till myndigheter och andra organisationer. Som redan nämnts kan det dessutom vara så att myndigheter och studieförbund på olika sätt uppmuntrat vissa riksförbund att särskilt prioritera samarbeten och kurser med kvinnofokus, när man ansett att sådana behov funnits.

\section{Opinionsbildning, verksambeter i ursprungslandet och transnationella förhållningssätt} Som nämnts inledningsvis syftar denna studie till att undersöka i vilken mån nyare typer av transnationell civilsamhällelig organisering vuxit fram inom det etniska organisationsfältet. Öppningar mot det transnationella rummet är framför allt synliga inom de verksamhetsområden som anknyter till opinionsbildning, men även, naturligtvis, till projekt som förlagts till ursprungslandet. Endast 8 av 52 riksförbund (ca 15 procent) redovisar verksamheter i ursprungslandet, huvudsakligen välgörenhetsprojekt av olika slag (se Figur 2). Den faktiska andelen kan möjligen vara något högre då det i intervjuerna omnämndes vissa aktiviteter, exempelvis insamlingar, som inte förekom i årsredovisningarna. Detta kan tolkas som ett tecken på att transnationaliseringen av det svenska etniska organisationsfältet varit måttlig och att de etniska organisationerna fortsatte att vara huvudsakligen förankrade i det svenska organisationslandskapet och orienterade mot svenska förhållanden.

Andelen som redovisade verksamheter i ursprungslandet var högre bland de europeiska riksförbunden, där 5 av 24 (en dryg femtedel) redovisade verksamheter i ursprungslandet jämfört med 2 av 12 MÖNA-riksförbund, 1 av de 10 afrikanska riksförbunden och inga av de asiatiska. Detta antyder att de europeiska etniska organisationerna var något mer benägna att aktivt engagera sig i ursprungslandet. Den geografiska närheten har sannolikt bidragit till detta, samtidigt som en större andel av de övriga etniska organisationerna var mer begränsade i detta avseende, av både geografiska och politiska skäl. Företrädare för en asiatisk organisation och en av MÖNA-organisationerna berättade exempelvis att de ansåg att det var alltför politiskt känsligt och riskabelt att bedriva verksamhet i ursprungslandet. I dessa fall 
uppfattades möjligheterna som blockerade. Trösklarna för fysiskt gränsöverskridande organisatoriska verksamheter tycks ha förblivit höga över tid. Det faktum att få etniska organisationer var direkt engagerade i ursprungsländerna ska dock inte tolkas som att de undvek engagemang kopplat till ursprungslandet, utan snarare att det tog sig andra uttryck, vilket vi ska se exempel på nedan.

33 av 52 (63,5 procent) riksförbund redovisade olika former av opinionsbildning eller lobbying, vilket gör den till den näst vanligaste aktivitetstypen (se Figur 2). Denna aktivitetskategori inkluderar politiska manifestationer, medie- och förlagsverksamhet samt olika former av lobbying gentemot politiker. Sett till ursprungsregion var opinionsbildning vanligast förekommande bland MÖNA-riksförbunden (16 av 24 eller 83 procent) och minst vanligt förekommande bland de asiatiska organisationerna (2 av 6). Många av de etniska organisationerna har sedan länge bedrivit medieverksamhet och opinionsbildning. Dessa verksamheter kan betraktas som centrala för den "röstfunktion" som förknippas med folkrörelsemodellen. Genom intervjuer framgick att förutsättningarna för de etniska organisationernas förmåga att upprätthålla delar av röstfunktionen hade förändrats mot bakgrund av de senaste decenniernas informationsteknologiska landvinningar. Några av de intervjuade företrädarna menade att efterfrågan på organisationernas medieverksamheter minskat kraftigt. Informationsteknologin verkar emellertid ha påverkat organisationerna på ganska olika sätt, eftersom röstfunktionen i flera fall tycks ha transnationaliserats snarare än marginaliserats. En företrädare för en MÖNA-organisation framhöll exempelvis att deras medlemsföreningar dragit fördel av informationsteknologin och sociala medier. Organisationen i fråga var aktivt regimkritiskt och arrangerade regelbundet demonstrationer mot regimen i ursprungslandet. Därutöver arbetade organisationen med nyhetsbevakning och använde sociala medier för att sprida information om händelser i ursprungslandet. Detta indikerar att i de fall där etniska organisationer kollektivt motarbetar regimen i ursprungslandet kan nyhetsförmedling och sociala medier ha en fortsatt viktig funktion, i detta fall för att förmedla regimkritiska nyheter. Detta är även ett exempel på att svenska etniska organisationers röstfunktion kan få omfattande transnationella förgreningar, eftersom webbaserade plattformar för regimkritik kan spridas bland migranter världen över.

På grundval av studiens kvalitativa material urskilde vi sex olika transnationella politiska förhållningssätt: regimkritik (som framgår ovan), formell samverkan, utrikespolitiskt lojal och inrikespolitiskt neutral, nationsbyggande, sociala remittanser och institutionsbyggande samt lobbying. Dessa förhållningssätt kunde syfta till förändring i Sverige (exempelvis av svensk utrikespolitik), global förändring eller förändring i ursprungslandet, i vissa fall samtidigt. Aktiviteterna var därför svåra att platsbestämma, såtillvida att de riktade sig mot ett transnationellt rum eller mot flera politiska och geografiska områden samtidigt.

Vissa riksförbund hade kontakter med diasporaministerier och dylikt i ursprungsländerna, och åtminstone ett riksförbund ingick i ett internationellt samarbetsråd som ursprungsstaten upprättat för samverkan med migrantorganisationer. Denna relation kan beskrivas i termer av formell samverkan, då riksförbundet hade valt att ingå i ett 
styrningsnätverk etablerat av ursprungsstaten, i detta fall en auktoritär regim. Vidare hade riksförbundet mottagit ett mindre bidrag från ursprungsstatens ambassad för att kunna finansiera olika högtidsarrangemang. Även detta riksförbund använde sociala medier och bedrev nyhetsförmedling via internet, dock i regimvänligt syfte, bland annat för att nyansera den svenska mediebilden av ursprungsstaten. I det här fallet hade alltså en etnisk organisation i Sverige inbegripits som nod i ett styrningsnätverk etablerat av en sändarstat. Även om sändarstater på olika sätt kan ha varit involverade i civilsamhälleliga organisationer tidigare tyder detta på att det kan vara fråga om en ny typ av organisationssambete, eller ett hybridformat om man så vill, som uppstått till följd av transnationaliseringen av det svenska civilsamhället.

Andra riksförbund företrädde en mer försiktigt lojal hållning till ursprungsstaten. Två riksförbund hade exempelvis valt att undvika att blanda sig i politiska skeenden i ursprungsländerna, samtidigt som de var engagerade i ursprungslandets utrikespolitik, främst ifråga om territoriella konflikter med grannländer. Denna hållning gentemot ursprungsstaten kan beskrivas som utrikespolitiskt lojal och inrikespolitiskt neutral. En förklaring till detta förhållningssätt var enligt företrädarna för förbunden att det förekommit inrikespolitisk oenighet bland medlemmarna, samtidigt som de enats i sin lojalitet mot ursprungslandet gentemot grannländerna.

En av de intervjuade företrädarna representerade en etnisk organisation som bedrev opinionsbildning och lobbying med det långsiktiga målet att upprätta en suverän nationalstat i ursprungsområdet, ett förhållningssätt som kan beskrivas som nationsbyggande. Riksförbundet hade bland annat etablerat en "vänskapsgrupp" i riksdagen som inbegrep företrädare för samtliga riksdagspartier. Dessutom deltog medlemmar i koordinerade demonstrationer i samarbete med diasporaorganisationer över hela Europa, vilket innebar att de svenska föreningarna också var noder i ett vittomspännande transnationellt nätverk. Detta kan ses som ett uttryck för en fördjupad transnationalisering av den röstfunktion som förknippats med svenska folkrörelseorganisationer. Som en följd av det kontinuerliga engagemanget i ursprungsområdet tycks medlemmar inom organisationen även ha skapat ett överbryggande socialt kapital inom Sverige, i form av kopplingar till exempelvis riksdagsledamöter och företrädare för invandrargruppen i Europa. Även om förbundets föreningar engagerade sig i ursprungslandet bidrog de alltså samtidigt till att förstärka förbundsmedlemmarnas möjligheter i Sverige. Det finns tecken på att även karriärfunktionen kan ha transnationaliserats då det organisatoriska engagemanget i ursprungsländerna verkar ha förstärkt medlemmarnas nätverkskontakter med exempelvis myndigheter och riksdagsledamöter i Sverige.

Denna tendens var möjligen än mer påtaglig inom det somaliska riksförbundet. Det somaliska riksförbundet ingick tillsammans med flera andra organisationer i ett samarbete med biståndsorganisationen Forum Syd. Som en följd av detta samarbete blev riksförbundet och dess medlemsföreningar involverade i olika styrningsnätverk med svenska myndigheter och biståndsorganisationer. Detta är ytterligare ett exempel på hur svenska civilsamhälleliga organisationer involverats som noder i nya typer av transnationella nätverk, i det här fallet med myndigheter och biståndsorganisationer.

Det somaliska riksförbundets förhållningsätt gentemot ursprungslandet var orien- 
terat mot sociala remittanser och institutionsbyggande, såtillvida att samarbetet officiellt syftade till att överföra svenska samhällsstyrnings- och organisationsformer till Somalia. Trots att dessa aktiviteter riktades mot ursprungslandet tycks de ha bidragit till att skapa och förstärka ett överbryggande socialt kapital som medlemmar kan dra fördel av i en svensk kontext. Även i detta fall fanns tecken på en transnationalisering av karriärfunktionen då det aktiva engagemanget i sändarlandet verkade generera nätverkskontakter som tjänar ett integrerande syfte i mottagarlandet. Vi menar att det finns skäl att vidare undersöka om det finns stöd för hypotesen att ett engagemang gentemot ursprungslandet under vissa omständigheter kan öka integrationsmöjligheterna i mottagarlandet. Ett tentativt resultat av denna studie är således teoretiskt, då vi tycker oss se tecken på vad som skulle kunna kallas hemlandsorienterad integration $i$ mottagarlandet. Denna tentativa integrationsfrämjande tendens innebär att invandrare som riktar ett politiskt engagemang mot hemlandet därmed skapar nätverkskontakter, socialt kapital, som främjar deras integrationsmöjligheter i mottagarlandet.

Det sjätte och sista transnationella förhållningssättet representeras av finlandssvenskarnas riksförbund. Riksförbundet verkar för att främja finlandssvenskars intressen både i Finland och Sverige, bland annat i syfte att ge finlandssvenskar nationell minoritetsstatus i Sverige. Detta förhållningsätt gentemot ursprungslandet och den svenska staten kan beskrivas i termer av intressentbaserad lobbying, då förbundet företräder en medlemsgrupp med väldefinierade och specifika intressen, som bedriver lobbying genom etablerade formella kanaler. Därmed kan detta förhållningssätt även ses som ett utryck för den traditionella civilsamhälleliga röstfunktionens kontinuitet.

Sammantaget antyder dessa varierade resultat att de etniska organisationerna verkade ha ett ganska stort handlingsutrymme i fråga om opinionsbildning. Vissa av organisationerna var däremot mer kringskurna inom de transnationella sociala fält som de förhöll sig till, främst vad gäller möjligheter till samarbete med ursprungsstaten. I vissa fall intog exempelvis staten i ursprungslandet en möjliggörande roll för de etniska organisationerna, medan andra upplevde att samarbeten med ursprungsstaten eller aktiviteter förlagda till ursprungslandet varken var önskvärda eller möjliga.

\section{Slutsatser och sammanfattande diskussion}

Denna artikel undersöker de statsstödda etniska organisationernas verksamheter - huvudsakligen såsom de redovisats i riksförbundens årsrapporter - $\mathrm{i}$ syfte att undersöka hur det etniska organisationsfältet förändrats i ljuset av de omregleringar och omvandlingar som på olika sätt påverkat det svenska civilsamhället. Studien visar att fältet kännetecknas av både kontinuitet och förändring. En ganska stor andel av de etniska organisationerna har tillkommit under 1990-talet och 2000-talet, vilket innebär att organisationsmångfalden inom fältet har ökat under de senaste decennierna. Därtill har fältet präglats av tilltagande fragmentering i meningen att det etablerats fler riksförbund som representerar samma etniska grupp eller nationalitet. Samtidigt är det tydligt vid en jämförelse med tidigare forskning att detta organisationsfält också utmärks av kontinuitet, då de etniska organisationernas kärnverksamheter tycks ha bestått över tid. Kulturella aktiviteter är 
fortsatt i särklass vanligast. Dessa arrangerades ofta i samverkan med olika studieförbund, vilket tyder på att folkrörelsemodellens inflytande över fältet är fortsatt stark. Det fanns dock ganska stora skillnader mellan organisationerna, då det var betydligt vanligare med integrationsfrämjande aktiviteter inom MÖNA-organisationerna jämfört med de europeiska. Det fanns vidare tecken på förändring i en mer kvalitativ bemärkelse då flera etniska organisationer tycks ha iklätt sig rollen som serviceproducent - exempelvis som informatör och förmedlare - för att bistå medlemmar med att orientera sig gentemot olika myndigheter. I samband med flyktingkrisen blev detta uppdrag särskilt centralt för några av de etniska organisationerna. Detta tyder dels på att organisationerna svarade mot väldigt skilda medlemsbehov, dels på att etniska organisationer vid behov tycks drivas till att försöka främja integration på olika sätt. Det fanns vidare tecken på att aktiviteter riktade till kvinnor blivit vanligare och fått en mer framträdande roll under 2000-talet och 2010-talet, vilket kan vara en följd av att jämställdhetsfrågor fått ett allt större genomslag över tid. Det är möjligt att svenska myndigheter och studieförbund haft ett fortsatt inflytande över fältet genom att tillhandahålla och uppmuntra vissa samarbeten, huvudsakligen kurssamarbeten, som riktats särskilt mot vissa av de etniska organisationerna.

Liksom vid tiden kring millennieskiftet bedrev merparten av de etniska organisationerna inga verksamheter i ursprungslandet. Detta var sannolikt en konsekvens av att trösklarna för direkta gränsöverskridande verksamheter förblivit höga. Det här resultatet ska dock inte ses som en indikation på bristande transnationellt engagemang. Snarare tog sig det transnationella engagemanget andra uttryck. Den opinionsbildnings- och "röstfunktion" som traditionellt förknippats med folkrörelseorganisationerna tycks delvis ha transnationaliserats, bland annat genom att svenska etniska organisationer tillhandahöll regimkritiska nätplattformar för nyhetsförmedling som hade en räckvidd utanför landets gränser. Svenska etniska organisationer hade dessutom i flera fall involverats som noder i olika transnationella nätverk som etablerats av sändarstater, svenska myndigheter, biståndsorganisationer och internationella diasporanätverk. I detta avseende verkar det vara fråga om en framväxt av nya samverkansformer, hybridformer om man så vill, som uppstått till följd av att det skett en vidare öppning mot olika transnationella rum. Det organisatoriska fältet präglades även av kontinuitet avseende opinionsbildning, då flera organisationer verkade bedriva denna verksamhetstyp på ungefär samma sätt som de gjort under längre tid. Variationen i de etniska organisationernas transnationella opinionsbildning var alltså ganska omfattande och vi urskilde sex olika förhållningsätt i detta avseende. Slutligen tyckte vi oss se tecken på att den karriärfunktion som också förknippats med folkrörelseorganisationerna verkar ha tagit sig nya uttryck med transnationella förtecken. I några fall förefaller ett starkt organisatoriskt engagemang riktat mot ursprungslandet ha resulterat i att förstärka de berörda medlemmarnas nätverkskontakter i Sverige, vilket kan ha bidragit till att öka deras integrationsmöjligheter här. Även om karriärfunktionen förändrats finns det skäl att tro att vissa etniska organisationer fortfarande upprätthåller den, om än i något mer transnationell tappning.

En slutsats är att utvecklingen inom det svenska etniska organisationsfältet uppvisar 
tecken på spårbunden kontinuitet, samtidigt som det finns nya inslag och tydliga tecken på förändring, i synnerhet när det gäller transnationella samverkansformer och indikationer på att det skett en viss transnationalisering av "röst- och karriärfunktionerna".

\section{Tillkännagivande}

Studien är finansierad av Marianne och Marcus Wallenbergs stiftelse, dnr MMW 2017.0011. En engelskspråkig artikel som bygger på samma databas, med titeln "Integration, cultural preservation and transnationalism through state supported immigrant organizations. A study of Sweden's national ethnic associations", har publicerats i tidskriften Comparative Migration Studies, volym 9 (2021).

Vi vill rikta ett tack till de anonyma fackgranskarna och till redaktörerna för Sociologisk Forskning för värdefulla kommentarer på tidigare utkast av artikeln.

\section{Referenser}

Bloch, A. \& S. Hirsch (2018) "Inter-generational transnationalism. The impact of refugee backgrounds on second generation”, Comparative Migration Studies 6 (30). https://doi.org/10.1186/s40878-018-0096-0

Boije, E. \& M. Ottervik (2014) "Svenskarna och civilsamhället", 255-268 i A. Bergström \& H. Oscarsson (red.) Mittfära och marginal. SOM-undersökningen 2013. Göteborg: SOM-institutet.

Borevi, K. (2004) "Den svenska diskursen om staten, integrationen och föreningslivet.", 31-64 i Integrationspolitiska maktutredningens forskningsprogram, Föreningsliv, makt och integration. Rapport frän Integrationspolitiska maktutredningens forskningsprogram. Ds 2004:49. Stockholm: Justitiedepartementet.

Campbell, J.R. \& S. Afework (2015) "Ethiopian and Eritrean immigrants in Britain. Refugee organising, transnational connections and identity, 1950-2009", African Diaspora 8 (1):98-119. https://doi.org/10.1163/18725465-00801005

Chaudhary, A.R. \& D.M. Moss (2019) "Suppressing transnationalism. Bringing constraints into the study of transnational political action", Comparative Migration Studies 7 (9). https://doi.org/10.1186/s40878-019-0112-z

Collyer, M. \& R. King (2015) "Producing transnational space. International migration and the extra-territorial reach of state power", Progress in Human Geography 39 (2):185-204. https://doi.org/10.1177/0309132514521479

Dahlstedt, I. (2003) "Invandrarorganisationer i Sverige”, 27-94 i F. Mikkelsen (red.) Indvandrerorganisationer i Norden. Köpenhamn: Nordiska ministerrådet och Akademiet for Migrationsstudier i Danmark.

Dahlstedt, M., A. Ålund \& A. Ålund (2010) "Villkorat partnerskap. Demokrati och social inkludering i relationer mellan bildningsförbund och föreningar bildade på etnisk grund", Dansk Sociologi 21 (4):75-94. https://doi.org/10.22439/dansoc.v21i4.3411

Dahlström, C. (2004). Nästan välkomna. Invandrarpolitikens retorik och praktik. Göteborg: Göteborgs universitet. 
Délano Alonso, A. \& H. Mylonas (2019) "The microfoundations of diaspora politics. Unpacking the state and disaggregating the diaspora", Journal of Ethnic and Migration Studies 45 (4):473-491. https://doi.org/10.1080/1369183x.2017.1409160

DiMaggio, P.J. \& W.W. Powell (1983) "The iron cage revisited. Institutional isomorphism and collective rationality in organizational fields", American Sociological Review 48 (2):147-160. https://doi.org/10.2307/2095101

Emami, A. (2004) "Institutionaliserade relationer, fria organisationer-om sverigeiraniers föreningsliv", 163-196 i Integrationspolitiska maktutredningens forskningsprogram, Föreningsliv, makt och integration. Rapport frän Integrationspolitiska maktutredningens forskningsprogram. Ds 2004:49. Stockholm: Justitiedepartementet.

Emami, A. (2017) "Drömmen om ett iranskt paneuropeiskt förbund", 101-148 i M. Reuter, F. Wijkström \& A. Emami (red.) Civilsamhället i det transnationella rummet. Stockholm: European Civil Society Press.

Huynh, J. \& J. Yiu (2015) "Breaking blocked transnationalism. Intergenerational change in homeland ties”, 160-186 i A. Portes \& P. Fernández-Kelly (red.) The state and the grassroots. Immigrant transnational organizations in four continents. New York: Berghahn Books. https://doi.org/10.2307/j.ctt9qd9c9.11

Klijn, E.-H. \& C. Skelcher (2007) "Democracy and governance networks. Compatible or not?", Public Administration 85 (3):587-608. https://doi.org/10.1111/j.14679299.2007.00662.x

Koinova, M. (2018) "Critical junctures and transformative events in diaspora mobilisation for Kosovo and Palestinian statehood", Journal of Ethnic and Migration Studies 44 (8):1289-1308. https://doi.org/10.1080/1369183x.2017.1354158

Lundberg, E. (2015) Det postkorporativa deltagandet. Intresseorganisationerna i den nationella politiken”, 293-356 i 2014 àrs demokratiutredning, Làt fler forma framtiden! Forskarantologi. SOU 2015:96. Stockholm: Wolters Kluwer.

MUCF (2018) Organisationsbidragens användning och effekter 2018. Aterrapportering av tre statsbidrag till ideella organisationer. Stockholm: Myndigheten för ungdoms- och civilsamhällesfrågor

Odmalm, P. (2004). "Invandrarföreningar som intressekanaler - möjligheter och hinder på lokal nivå”, 99-128 i Integrationspolitiska maktutredningens forskningsprogram, Föreningsliv, makt och integration. Rapport frän Integrationspolitiska maktutredningens forskningsprogram. Ds 2004:49. Stockholm: Justitiedepartementet.

Portes, A. \& P. Fernández-Kelly (2015) The state and the grassroots. Immigrant transnational organizations in four continents. New York: Berghahn Books. https://doi. org/10.2307/j.ctt9qd9c9

Ragin, C.C. (1987) The comparative method. Moving beyond qualitative and quantitative strategies. Berkeley: University of California Press.

Reuter, M. (2017) "Nationalstatens sista väktare”, 185-218 i M. Reuter, F. Wijkström \& A. Emami (red.) Civilsambället $i$ det transnationella rummet. Stockholm: European Civil Society Press.

Reuter, M., F. Wijkström \& A. Emami (2017) "Idéer som reser, containrar som formaterar", 1-33 i M. Reuter, F. Wijkström \& A. Emami (red.) Civilsambället i det 
transnationella rummet. Stockholm: European Civil Society Press.

Scaramuzzino, R. (2013) I statens tjänst. Så påverkas invandrarorganisationer av politiska krav och förväntningar. Stockholm: Sektor 3.

SCB (2017) Det civila sambället 2017. Satelliträkenskaper. Örebro: Statistiska centralbyrån.

Schierup, C.-U. (1991a) "The ethnic tower of babel. Political marginality and beyond", 113-136 i A. Ålund \& C.-U. Schierup (red.), Paradoxes of multiculturalism. Essays on Swedish society. Aldershot: Avebury.

Schierup, C.-U. (1991b) "Ett etniskt Babels torn. Invandrarorganisationerna och den uteblivna dialogen", Sociologisk Forskning 28 (3):3-22.

Snel, E., M. 'T Hart \& M. van Bochove (2016) "Reactive transnationalism. Homeland involvement in the face of discrimination", Global Networks 16 (4):511-530. https:// doi.org/10.1111/glob.12125

SFS 2008:63. Förordning om statsbidrag till organisationer bildade på etnisk grund. Stockholm: Arbetsmarknadsdepartementet.

Takle, M. (2015) "Immigrant organisations as schools of bureaucracy", Ethnicities 15 (1):92-111. https://doi.org/10.1177/1468796814546575

Torfing, J. (2012) "Governance networks", 99-112 i D. Levi-Faur (red.), The Oxford handbook of governance. Oxford: Oxford University Press. https://doi.org/10.1093/ oxfordhb/9780199560530.013.0007

Wijkström, F. (2015) "Filantroper, frivilliga och sociala entreprenörer. Nya civilsamhällesmedborgare i ett omförhandlat samhällskontrakt", 61-103 i S. Sörlin, J.M. Stenøien, U. Carlsson, G. Wagner \& F. Wijkström (red.) Medborgarnas Europa. Civilsamhällets utmaningar. Stockholm: Folkuniversitetet.

Wijkström, F. (2017) "Nytt svängrum för filantropi och frivillighet”, 379-416 i M. Reuter, F. Wijkström \& A. Emami (red.) Civilsamhället i det transnationella rummet. Stockholm: European Civil Society Press.

\section{Författarpresentation}

Olle Frödin är docent i sociologi vid Lunds universitet. Hans forskningsintressen rör främst globalisering, arbetsmarknad och samhällsstyrning.

Axel Fredholm är universitetslektor i sociologi vid Lunds universitet. Hans forskningsintressen rör främst svensk skolpolitik, migration och internationellt utvecklingssamarbete.

\section{Kontaktuppgifter}

Olle Frödin

Sociologiska institutionen

Lunds universitet, Box 114, 22100 Lund

olle.frodin@soc.lu.se 